Z. Klin. Chem. Klin. Biochem.

12. Jg. 1974 , S. $62-65$

\title{
Effect of Ascorbic Acid 2-Sulfate on the Faecal Excretion of Exogenous Cholesterol in the Rat
}

\author{
By D. Hornig, F. Weber and $O$. Wiss
}

F. Hoffmann-La Roche \& Co., Basle

(Eingegangen am 13. September/12. Dezember 1973)

\begin{abstract}
The influence of intravenously administered ascorbic acid 2-sulfate, sodium ascorbate, or $\mathrm{K}_{2} \mathrm{SO}_{4}$, given over a period of 5 days, on the excretion behaviour of an exogenous dose of ${ }^{14} \mathrm{C}$-labelled cholesterol was studied in normal female rats. No stimulatory effect of ascorbic acid 2-sulfate or ascorbate was observed either on the faecal excretion of cholesterol or on that of cholesterol sulfate. On the contrary, the excretion of radioactive material was significantly reduced after treatment with either ascorbic acid 2-sulfate or with ascorbate when compared with the controls (treatment with buffer or $\mathrm{K}_{2} \mathrm{SO}_{4}$ ). The composition of the radioactive material in the faeces was unaffected (cholesterol $90 \%$, cholesterol sulfate $6 \%$ ). Therefore, it is doubtful that the hypocholesterolemic effect of ascorbic acid is due to the intermediate formation of ascorbic acid 2 -sulfate.
\end{abstract}

Es wurde der Einfluß von Ascorbinsäure-2-sulfat, von Natriumascorbat und von Kaliumsulfat auf die Ausscheidung einer einzigen exogenen Dosis von ${ }^{14} \mathrm{C}$-markiertem Cholesterin in weiblichen Ratten untersucht. Ascorbinsäure-2-sulfat, Natriumascorbat und Kaliumsulfat wurden täglich über 5 Tage intravenös appliziert. Das markierte Cholesterin wurde $5 \mathrm{~h}$ nach der letzten Dosis dieser Substanzen injiziert. Der Kot wurde $72 \mathrm{~h}$ gesammelt. Weder Ascorbinsäure-2-sulfat noch Ascorbat zeigten eine Stimulierung der Ausscheidung an Cholesterin und Cholesterinsulfat mit dem Kot. Im Vergleich zu den Kontrollen (Verabreichung von Puffer oder Kaliumsulfat) ergab sich sogar eine signifikante Verminderung der Ausscheidung von markiertem Material. Die Zusammensetzung der ${ }^{14} \mathrm{C}-$ markierten Substanzen im Kot zeigte sich unbeeinflußt (Cholesterin 90\%; Cholesterinsulfat, 6\%). Die Ergebnisse verneinen die Hypothese, daß die hypocholesterolämische Wirkung der Ascorbinsäure auf eine intermediäre Bildung von Ascorbiñsäure-2-sulfat mit anschließendem Sulfattransfer auf Cholesterin zurückzuführen sei.

Ascorbic acid 2-sulfate was shown to serve as a sulfating agent in vitro at elevated temperature or under mild oxidizing conditions $(1,2)$. The in vivo sulfation of cholesterol by ascorbic acid 2-sulfate in the rat was recently reported $(3,4)$. A single intracardial injection of $\left[{ }^{35}\right.$ S] ascorbic acid 2-sulfate elevated the faecal excretion of cholesterol sulfate approximately fifty-fold. The hypocholesterolemic effect of ascorbic acid, as reported in man (5) as well as in laboratory animals $(6,7)$, was postulated to be due to the intermediate synthesis of ascorbic acid 2-sulfate with subsequent transfer of the activated sulfate moiety onto cholesterol to form cholesterol sulfate which is then flushed out of the body (4). Ascorbic acid 2-sulfate was identified as a significant metabolite of ascorbic acid in animals and man $(8-10)$ and it has been suggested that it acts as a long-term storage form in the ascorbic acid pool of the body (11).

This report deals with the effect of ascorbic acid 2-sulfate, given over a period of 5 days by daily intravenous injection, on the faecal excretion of radioactivity after a single intravenous administration of $\left[4-{ }^{14} \mathrm{C}\right]$ cholesterol in rats. The aim of this study was to examine whether the administration of ascorbic acid 2-sulfate enhances the faecal or urinary excretion of radioactive material, especially of cholesterol sulfate, and whether the accumulation of exogenous cholesterol by various tissues is decreased.

\section{Materials and Methods}

Chemicals: $\left[4-{ }^{14} \mathrm{C}\right]$ cholesterol $(55.6 \mathrm{mCi} / \mathrm{mmole})$, dissolved in benzene, was purchased from The Radiochemical Centre, Amersham. Ascorbic acid 2-sulfate (dipotassium salt), sodium ascorbate and cholesterol sulfate (ammonium salt) were supplied by Hoffmann-La Roche, Atlas G-1290 by Atlas Chemie (Essen, Germany). All other chemicals were of reagent grade and from commercial sources.

Animals: Female rats (strain Füllinsdorf Albino) were maintained on a commercial diet (Nafag 199, by Nafag, Gossau, Switzerland). They were divided into 3 groups (SD given): controls (167.1 $\pm 9.4 \mathrm{~g}$ of weight) and two experimental groups receiving $10 \mathrm{mg}$ ascorbic acid 2-sulfate daily $(165.7 \pm 16.2 \mathrm{~g})$ or $20 \mathrm{mg}$ ascorbic acid 2-sulfate daily $(165.2 \pm 15.0 \mathrm{~g})$. Ascorbic acid 2-sulfate was dissolved in $0.15 \mathrm{~mol} / 1$ sodium phosphate buffer, $\mathrm{pH} 7.4$, to a final concentration of 10 or $20 \mathrm{mg} / 500 \mu \mathrm{l}$. The solutions were injected daily for 5 days via the tail vein. The control animals were injected with only the buffer $(500 \mu \mathrm{l}) .7$ animals were taken for each experiment. Additional controls ( 2 animals) received a solution of sodium ascorbate ( $33 \mathrm{mg} / 500 \mu \mathrm{l}$ buffer) or a solution of $\mathrm{K}_{2} \mathrm{SO}_{4}$ (Merck, $10 \mathrm{mg} / 500 \mu \mathrm{l}$ buffer). A single dose of $22.8 \mu \mathrm{Ci}[4-14 \mathrm{C}]$ cholesterol $(159 \mu \mathrm{g})$ was administered via the same route in an emulsified form $(300 \mu \mathrm{l}) 5 \mathrm{~h}$ after the last injection of ascorbic acid sulfate, sodium ascorbate or $\mathrm{K}_{2} \mathrm{SO}_{4}$. This emulsion was prepared as follows: the benzene was evaporated from the cholesterol solution and the residue was emulsified in isotonic $\mathrm{NaCl}$ after addition of a small volume of emulgator Atlas G-1290 and propylene glycol. The animals were kept for $72 \mathrm{~h}$ in metabolic cages for the collection of faeces and urine. They had free access to the diet. After decapitation, the abdomen was opened and the liver, spleen, kidneys and adrenal glands were removed and processed for counting of radioactivity. Counting of the radioactive material: The faeces were homogenized with a 4-fold amount of water (Polytron, Kinematica, 
Lucerne, Switzerland) and incubated for $10 \mathrm{~min}$ at $60^{\circ} \mathrm{C}$. The radioactive material was extracted from the homogenate at room temperature several times with chloroform/methanol, $10 \mathrm{ml}+10 \mathrm{ml}$ (15-fold volume). After centrifugation, the supernatants were brought to a constant volume $(250 \mathrm{ml})$. Aliquots were counted for radioactivity and were used for chromatographic identification of the labelled material. The urine was directly counted for radioactivity $(100 \mu \mathrm{l})$. Solubilization of the tissues (approx. $50 \mathrm{mg}$ ) was achieved with Soluene-100 solubilizer (Packard) as described in detail elsewhere (12). The radioactivity was determined using a Nuclear Chicago Unilux II liquid scintilation spectrometer equipped with an Olivetti Programma 101 computerized for direct calculation of disintegrations per min (dpm). The external standard method for quenche correction was employed. A mixture of ethanol and scintillator solution ( $8 \mathrm{~g}$ Butyl-PBD [CIBA]/1 toluene), 4:15, volumes, was used for counting.

Chromatography: The extracts from the faeces were chromatographed on thin-layer plates (silica gel $F_{254}$, Merck). Solvent systems were as follows: (I) benzene/ethanol/methylethylketone/water, $30 \mathrm{ml}+30 \mathrm{ml}+30 \mathrm{ml}+10 \mathrm{ml} \cdot(13)$ and (II) ethylacetate/pyridine/acetic acid/water, $62 \mathrm{ml}+21 \mathrm{ml}+6 \mathrm{ml}+1 \mathrm{ml}$ (14). As standards, cholesterol, cholesterol sulfate and sodium taurocholate were used. For the quantitative determination of the composititon of the radioactive material in the faeces, system II was employed. The 3 labelled fractions were eluted with chloroform/methanol $(10 \mathrm{ml}+50 \mathrm{ml}$, unpolar zone, cholesterol and triglycerides) or with chloroform $/$ methanol $(20 \mathrm{ml}$ $+10 \mathrm{ml}$, cholesterol sulfate-containing zone) or with chloroform (polar zone, sodium taurocholate). The solvents were evaporated and the amounts of radioactivity were determined in the residues. Student's t-test was used for statistical evaluation of the data (15).

\section{Results}

In Table 1 , the values for the total faecal as well as urinary excretion of ${ }^{14} \mathrm{C}$-radioactivity are given. A significant reduction in the faecal excretion of radioactive material was seen in the first $72 \mathrm{~h}$ after the administration of $\left[4{ }^{14} \mathrm{C}\right]$ cholesterol to rats which had been treated for a period of 5 days with a daily injection of $10 \mathrm{mg}$ or $20 \mathrm{mg}$ ascorbic acid 2-sulfate $(27.2 \%$ or $28.3 \%$ of the labelled dose); the controls received an injection of buffer only $(33.9 \%)(\mathrm{p}<0.02$ and $\mathrm{p}<0.01$, respectively), or a solution containing $10 \mathrm{mg}$ $\mathrm{K}_{2} \mathrm{SO}_{4}(32.6 \%)$. However, sodium ascorbate $(33 \mathrm{mg})$ had a similar effect to ascorbic acid 2-sulfate, with regard to the excretion of radioactivity in the faeces ( $25.8 \%$ of the administered dose). The urinary excretion of ${ }^{14} \mathrm{C}$-radioactivity was found to be enhanced
Tab. 2. Percentage composition of the radioactive material excreted in the faeces after $i$. v. injection of $22.8 \mu \mathrm{Ci}$ $[4-14 \mathrm{C}]$ cholesterol into female rats. Treatment prior to application of cholesterol and number of animals as in Table 1 . The radioactivity was extracted from the faeces with chloroform/methanol and the extracts were chromatographed on silica gel-coated plates.

\begin{tabular}{lccll}
\hline $\begin{array}{l}\text { Administered } \\
\text { compound }\end{array}$ & \multicolumn{4}{c}{ Per cent of excreted radioactivity } \\
& mg/day & Cholesterol & $\begin{array}{l}\text { Cholesterol } \\
\text { sulfate }\end{array}$ & $\begin{array}{l}\text { Polar } \\
\text { fraction }\end{array}$ \\
\hline $\mathrm{Na}^{+}$-ascorbate & 33 & 90.0 & 6.1 & 3.9 \\
$\mathrm{~K}_{2} \mathrm{SO}_{4}$ & 10 & 93.8 & 3.9 & 2.3 \\
Buffer $_{\text {Ascorbic acid }}$ & 10 & 89.9 & 6.2 & 3.9 \\
2-sulfate & 20 & 90.7 & 6.3 & 4.0 \\
\hline
\end{tabular}

following the injection of $10 \mathrm{mg}$ or $20 \mathrm{mg}$ ascorbic acid 2 -sulfate $(2.2 \%$ or $2.5 \%$ of the dose: treatment with buffer, $1.6 \%$ ). The application of sodium ascorbate (33 mg), or $\mathrm{K}_{2} \mathrm{SO}_{4}$ (10 mg) caused an even higher excretion (3.7\% and $3.9 \%$, respectively).

Table 2 summarizes the quantitative composition of the labelled material in the faeces. Cholesterol and triglycerides (unpolar zone) accounted for nine-tenths of the radioactivity, whereas only approx. $6 \%$ were found as cholesterol sulfate. The polar fraction contained $3-4 \%$ of the label. No stimulatory effect on the excretion of either cholesterol or cholesterol sulfate could be observed by ascorbic acid 2-sulfate as compared with the controls (buffer, sodium ascorbate or $\mathrm{K}_{2} \mathrm{SO}_{4}$ ).

The total radioactivity remaining in the liver, spleen, kidneys and adrenals $72 \mathrm{~h}$ after the single injection of $\left[4-{ }^{14} \mathrm{C}\right.$ ]cholesterol is given in Table 3 . The accumulation of label was higher in the organs of rats injected with ascorbic acid 2-sulfate. No significant difference existed either in the liver, spleen, or in the kidneys of rats in the ascorbic acid 2-sulfate treated group. However, a significant increase in the accumulation of radioactivity was found in the adrenal glands after treating rats with $20 \mathrm{mg}$ ascorbic acid 2 -sulfate $(p<0.02)$, but the total radioactivity did not reach the amounts observed after dosage of either sodium ascorbate or $\mathrm{K}_{2} \mathrm{SO}_{4}$. The weights of the organs per $100 \mathrm{~g}$ of body weight were not influenced by the treatment with ascorbic acid 2-sulfate.

Tab. 1. Total faecal and urinary excretion of ${ }^{14} \mathrm{C}$-radioactivity $(\mu \mathrm{Ci}$, rounded figures, SD given) during the first $72 \mathrm{~h}$ after i. v. injection of $22.8 \mu \mathrm{Ci}\left[4-{ }^{14} \mathrm{C}\right.$ ]cholesterol $(159 \mu \mathrm{g})$ to female rats which had been treated for 5 days with a daily injection of ascorbic acid 2-sulfate dipotässium salt (10 or $20 \mathrm{mg}, \mathrm{n}=7$ ) in $0.15 \mathrm{~mol} / 1$ sodium phosphate buffer (pH 7.4) or with buffer. For additional controls, 2 animals were injected either with $33 \mathrm{mg}$ sodium ascorbate in buffer or with $10 \mathrm{mg} \mathrm{K}_{2} \mathrm{SO}_{4}$ in buffer. The faeces were extracted as dèscribed in the experimental part; the urine $(100 \mu \mathrm{l})$ was directly counted for radioactivity.

\begin{tabular}{|c|c|c|c|c|c|}
\hline $\begin{array}{l}\text { Compound } \\
\text { (mg/day) }\end{array}$ & $\begin{array}{l}\mathrm{Na}^{+} \text {-ascorbate } \\
33\end{array}$ & $\begin{array}{l}\mathrm{K}_{2} \mathrm{SO}_{4} \\
10\end{array}$ & Buffer & $\begin{array}{l}\text { Ascorbic acid 2-sulfate } \\
10\end{array}$ & 20 \\
\hline \multicolumn{6}{|c|}{ Total radioactivity $(\mu \mathrm{Ci})$} \\
\hline $\begin{array}{l}\text { Faeces } \\
\text { Urine }\end{array}$ & $\begin{array}{l}5.89 \\
0.87\end{array}$ & $\begin{array}{l}7.44 \\
0.89\end{array}$ & $\begin{array}{l}7.73 \pm 0.56^{* * * *} \\
0.37 \pm 0.07^{*}\end{array}$ & $\begin{array}{l}6.21 \pm 1.01^{* *} \\
0.50 \pm 0.13\end{array}$ & $\begin{array}{l}6.45 \pm 0.73^{* * *} \\
0.56 \pm 0.19 *\end{array}$ \\
\hline
\end{tabular}

* $\mathrm{p}<0.05 ; \quad * * \mathrm{p}<0.02 ; \quad * * * \mathrm{p}<0.01$.


Tab. 3. Total radioactivity ( $\mu \mathrm{Ci} / 100 \mathrm{~g}$ body weight; rounded figures, $\mathrm{SD}$ given) in various organs $72 \mathrm{~h}$ after $\mathrm{i}$. v. application of $22.8 \mu \mathrm{Ci}\left[4-{ }^{-14} \mathrm{C}\right]$ cholesterol $(159 \mu \mathrm{g})$ to female rats. Treatment prior to administration of cholesterol and number of animals as in Table 1 . Solubilization of the organs removed after decapitation was achieved by means of Soluene-100.

\begin{tabular}{|c|c|c|c|c|c|}
\hline $\begin{array}{l}\text { Compound } \\
\text { (mg/day) }\end{array}$ & $\begin{array}{l}\mathrm{Na}^{+} \text {-ascorbate } \\
33\end{array}$ & $\begin{array}{l}\mathrm{K}_{2} \mathrm{SO}_{4} \\
10\end{array}$ & Buffer & $\begin{array}{l}\text { Ascorbic äcid 2-sulfate } \\
10\end{array}$ & 20 \\
\hline \multirow{2}{*}{\multicolumn{6}{|c|}{ Total radioactivity ( $\mu \mathrm{Ci} / 100 \mathrm{~g}$ body weight) }} \\
\hline & & & & & \\
\hline Liver & 0.620 & 0.045 & $0.401 \pm 0.054$ & \multirow{4}{*}{$\begin{array}{l}0.482 \pm 0.099 \\
0.054 \pm 0.009 \\
0.068 \pm 0.005 \\
0.021 \pm 0,001\end{array}$} & $0.477 \pm 0.095$ \\
\hline Spleen & 0.068 & 0.068 & $0.050 \pm 0.014$ & & $0.068 \pm 0.018$ \\
\hline Kidneys & 0.095 & 0.081 & $0.054 \pm 0.014$ & & $0.068 \pm 0.014$ \\
\hline Adrenals & 0.054 & 0.045 & $0.012 \pm 0.004 *$ & & $0.024 \pm 0.009 *$ \\
\hline
\end{tabular}

* $\mathrm{p}<0.02$

\section{Discussion}

The effect of intravenously administered ascorbic acid 2 -sulfate, given over a period of 5 days, on the excretion of a single exogenous dose of $\left[{ }^{14} \mathrm{C}\right]$ cholesterol was studied in normal female rats. No stimulatory effect of this ascorbic acid derivative on the excretion of either free cholesterol or cholesterol sulfate could be observed. On the contrary, treatment with either sodium ascorbate $(33 \mathrm{mg})$ or ascorbic acid 2-sulfate $(10 \mathrm{mg}$ or $20 \mathrm{mg}$ ) caused a significant reduction of the total radioactivity excreted in the faeces (Table 1) in comparison with the results obtained after treatment with buffer or with $\mathrm{K}_{2} \mathrm{SO}_{4}(10 \mathrm{mg})$. However, the composition of the excreted radioactive material was unaffected (approx. 90\% cholesterol and 6\% cholesterol sulfate) (Table 2). The fact that the excretion of labelled material can be reduced by treatment with sodium ascorbate is surprising, since the rat is able to produce ascorbic acid biosynthetically (16). Since ascorbic acid sulfate treatment evoked a similar effect, the question arises whether sodium ascorbate can be converted enzymatically into ascorbic acid 2-sulfate which then could be considered as the active compound. Several reports have appeared indicating an in vivo sulfatation of ascorbic acid into ascorbic acid 2-sulfate. After the oral administration of labelled ascorbic acid, ascorbic acid sulfate was shown to be excreted in the bile $(9,17)$. Following the subcutaneous injection of $\left[{ }^{14} \mathrm{C}\right]$ ascorbic acid and ${ }^{35} \mathrm{SO}_{4}^{2-}$ into rats, $\left[1{ }^{14} \mathrm{C}\right]$ ascorbic acid $2-\left[{ }^{35} \mathrm{~S}\right]$ sulfate was identified in the liver as well as in other tissues (10). Ascorbic acid 2-[ $\left.{ }^{35} \mathrm{~S}\right]$ sulfate was also found in the rat liver after the intravenous injection of ${ }^{35} \mathrm{SO}_{4}^{2-1}$ ). Since ascorbic acid 2-sulfate has been suggested to be part of the ascorbic acid body pool as a long-term storage form (8), one might even assume that ascorbic acid 2-sulfate can only evoke this decrease in faecal ex-

1) Hornig, D. (1973) in preparation.

2) Hamilton, J. (1973) in preparation. cretion after administration of cholesterol as long as this derivative of ascorbic acid is not integrated in the ascorbic acid body pool. Our results are in accordance with the observation that the sulfate moiety of ascorbic acid 2-sulfate can be transferred in vivo onto cholesterol to form cholesterol sulfate $(3,4)$. However, the enhancement of the faecal excretion of cholesterol sulfate by ascorbic acid 2-sulfate could not be confirmed (Table 2). This was postulated from observations following the intracardial injection of a single dose of ascorbic acid $2 \cdot\left[{ }^{35} \mathrm{~S}\right]$ sulfate into rats. This would mean that the effect of ascorbic acid 2-sulfate on the endogenous cholesterol was investigated, whereas in our study the effect of ascorbic acid 2-sulfate was studied on exogenously administered cholesterol. However, in studies with rats in which the cholesterol pool was gradually labelled by the intravenous application of $\left[{ }^{14} \mathrm{C}\right] \mathrm{meva}$ lonate prior to intraperitoneal treatment with ascorbic acid 2-sulfate, there was still no stimulatory effect on the cholesterol metabolism with regard to an enhanced excretion of ${ }^{14} \mathrm{C}$-labelled material in the faeces ${ }^{2}$ ). From our studies it is to be concluded that the hypo- cholesterolemic effect of ascorbic acid is not attributable to ascorbic acid 2-sulfate.

In the adrenal glands the amount of ${ }^{14} \mathrm{C}$-radioactivity was found to be about twice as much in sodium ascorbate-treated rats as compared with rats pretreated with ascorbic acid 2-sulfate. On the other hand, the administration of ascorbic acid enhanced the concentration of labelled material derived from $\left[{ }^{14} \mathrm{C}\right]$ cholesterol in the adrenals significantly (Table 3 ). This observation might possibly be related to an increased hydroxylation of cholesterol at position C-7 by ascorbic acid 2-sulfate. In guinea pig liver homogenates cholesterol is mainly converted to $7 \alpha$-hydroxycholest-4-en-3-one (18). Recently, a control function was suggested for ascorbic acid in the transformation of cholesterol to bile acids (19). Thus, it would be of interest to study the possible effect of ascorbic acid 2-sulfate in this transformation reaction. 


\section{References}

1. Mumma, R. O. (1968) Biochim. Biophys. Acta 165, 571573.

2. Chu, T. M. \& Slaunwhite, Jr., W. R. (1968) Steroids 12 , 309-321.

3. Mumma, R. O. \& Verlangieri, A. J. (1971) Fed. Proc., Fed. Amer. Soc. Exp. Biol. 30, 370.

4. Verlangieri, A. J. \& Mumma, R. O. (1973) Atherosclerosis $17,37-48$.

5. Sokoloff, B., Hori, M., Saelhof, C., Wrzolek, T. \& Imai, T. (1966) J. Amer. Geriatr. Soc. 14, 1239-1260.

6. N. N., Nutr. Rev. (1967) 25, 183-185.

7. Ginter, E., Bobek, P., Kopec, Z., Ovecka, N. \& Cerey, K. (1967) Z. Versuchstierk. 9, 228-235.

8. Baker, E. M., Hammer, D. C., March, S. C., Tolbert, B. M. \& Canham, J. E. (1971) Science 173, 826-827.

9. Hornig, D. \& Gallo-Torres, H. E. (1972) Scand. J. Clin. Lab. Invest. 29, Suppl. 126, abstr. 31-4.

10. Mumma, R. O. \& Verlangieri, A. J. (1973) Biochim. Biophys. Acta 273, 249-253.
11. Baker, E. M., Kennedy, J. E., Tolbert, B. M. \& Canham, J. E. (1972) Fed. Proc., Fed. Amer. Soc. Exp. Biol. 31, 705.

12. Hornig, D., Gallo-Torres, H. E. \& Weiser, H. (1972) Int. J. Vit. Nutr. Res. 42, 487-496.

13. Wusteman, F. S., Dodgson, K. S., Lloyd, A. G., Rose, F. A. \& Tudball, N. (1964) J. Chromatogr. 16, 334-339.

14. Neher, R. (1967), in Dünnschicht-Chromatographie (Stahl, E., ed.) 2nd ed., p. 343, Springer-Verlag, Berlin-HeidelbergNew York

15. Fisher, R. A. \& Yates, F. (1963) Statistical Tables for Biological, Agricultural and Medical Research, p. 46, Oliver and Boyd, Edinburgh.

16. Isherwood, F. A. \& Mapson, L. W. (1961) Ann. N. Y. Acad. Sci. 92, 6-20.

17. Hornig, D., Gallo-Torres, H. E. \& Weiser, H. (1973) Biochim. Biophys. Acta 320, 549-556.

18. Björkhem, I., Danielsson, H. \& Einarsson, K. (1967) Eur. J. Biochem. 2, 294-302.

19. Ginter, E. (1973) Science 179, 702-704.
Dr. Dietrich Hornig,

Department of Vitamin and Nutritional Research, F. Hoffmann-La Roche \& Co., Ltd.,

Basle, Switzerland. 